\title{
OBSERVATIONS ON THE REPRODUCTION OF Pisania pusio (LINNAEUS, 1758) (MOLLUSCA: GASTROPODA: BUCINIDAE) IN LABORATORY.
}

\author{
HELENA MATTHEWS-CASCON $\mathbf{N}^{1,2^{*}}$ \\ HELTON ALEXANDRE PEREIRA ${ }^{1}$
}

\author{
${ }^{1}$ Universidade Federal do Ceará, Centro de Ciências, Departamento \\ de Biologia. Campus do Pici, Av. Mister Hull, s/n. 60455-760 \\ Fortaleza, CE, Brasil (hmc@ufc.br). \\ ${ }^{2}$ Instituto de Ciências do Mar (LABOMAR), Av. da Abolição 3207, \\ Meireles, 60165-081, Fortaleza, CE, Brasil. \\ *Autor correspondente.
}

Recebido: 30/06/2005

Aceito: 02/09/2005

\section{RESUMO}

\section{Obsevações na reprodução de Pisania pusio (Linnaeus, 1758) (Mollusca: Gastropoda : Bucinidae) em laboratório.}

O desenvolvimento larval e a desova de Pisania pusio foram descritas. As cápsulas de ovos eram de formato circular e translúcidas e mediram 2.9 to $3.7 \mathrm{~mm}(\mathrm{n}=52)$ em diâmetro, estas eram fixadas ao substrato por um pedúnculo. O poro de saída das larvas fica localizado no lado superior da cápsula e media $2.2 \mathrm{~mm}$ (n = 52) em diâmetro. No sétimo dia, foi observado o estágio de larva veliger intracapsular. O estágio intracapsular de pediveliger foi observado no décimo quarto dia, quando os animais já possuíam uma coloração escura na parte superior do pé e um "velum" reduzido. A eclosão ocorreu no quadragésimo dia em estágio final de pediveliger.

Palavras-chave: Gastropoda, Bucinidae, reprodução.

\begin{abstract}
Spawn and larval development stages of Pisania pusio from Northeast Brazil are described. The egg capsules were translucent with a circular shape which measured 2.9 to $3.7 \mathrm{~mm}(\mathrm{n}=52)$ in diameter and it had a stalk to fix the capsule to the substrate. The exit plug is located on the upper side of the capsule and measured $2.2 \mathrm{~mm}(\mathrm{n}=52)$ in diameter. At the seventh day, the intracapsular veliger stage was observed. The intracapsular pediveliger stage was observed by the fourteenth day, when the individuals had a dark color in the upper part of the foot and a reduced velum. Hatching as a late pediveliger stage occurred in the fourtyth day.
\end{abstract}

Key words: Gastropoda, Bucinidae, reproduction.

\section{INTRODUCTION}

The family Bucinidae is represented in Brazil for eight genus and fourteen species (Kryptos tholoides (Watson, 1881); Manaria fusiformes (Clench \& Aguayo, 1941); Prosipho mundus E.A.Smith, 1915 Prosipho tuberculatus E.A.Smith, 1915; Antillophos candei (Orbgny, 1842); Antillophos smithi Watson, 1885; Pisania auritula (Link,1802); Pisania pusio Linnaeus, 1758; Pisania tincta (Conrad, 1816); Caducifer atlanticus Coelho, Matthews \& Cardoso, 1970; Caducifer

Tropical Oceanography, Recife, v. 33, n. 2, p. 159-162, 2005. 
swifti (Tryon, 1881); Cantharus karinae Usticke, 1959; Engina corinnae Crovo, 1971; Engina turbinella (Kiener, 1835) (Rios, 1974).

Pisania pusio is very common in intertidal zone found under the rocks during the low tide associate with tunicates, sponges and calcareous algae. Pisania pusio presents spindle smooth and glossy shell measuring $34 \mathrm{~mm}$ of length, color purplish brown with narrow, revolving, dark- brown bands, sometimes in the shape of arrowheads and radula rachiglossate type (fig.1). In the present study the spawn aspects and the larvae development of the Pisania pusio were studied.

\section{MATERIALS AND METHODS}

In September of 2001, 60 adults of Pisania pusio were collected in the Pacheco beach, Caucaia county, Ceará state, northeast Brazil $\left(3^{0} 41^{\prime} \mathrm{S}, 38^{0} 37^{\prime} \mathrm{W}\right)$. The animals were transferred to the laboratory where they were kept in well-aerated 60 liters water tanks at a constant temperature $\left(28^{\circ} \mathrm{C}\right)$ and salinity (35) and fed ad libitum during nine months.

Between May and June of 2002, fifty two egg capsules were found in the tanks. To determine the duration of the development and the period until the eclosion, ten capsules were observed daily and had the stage of development of most individuals registered.

Egg capsules were measured with a slide under a stereoscopic microscope. The egg capsules were photographed with a camera linked to a stereoscopic microscope.

\section{RESULTS}

The egg capsules were translucent with a circular shape and it had a stalk to fix the capsule to the substrate; that could be a dead shell, rock or the aquarium wall (fig. 2). The egg capsules measure between 2.9 and $3.7 \mathrm{~mm}$ in diameter. Each capsule has an exit plug located on the upper side of the capsule. The plug covering this exit aperture was opaque with an elliptical shape, measuring in mean $2.2 \mathrm{~mm}$ in diameter.

The early veliger stage had been reached by the seventh day. In fourteenth days the pediveliger larvae, started showed a dark color in the upper part of the foot, as it is found in the adults and juveniles of this species. In the twenty first days the shell got opaque and the anterior siphonal canal was showed. Hatching as a late pediveliger stage occurred in fourtyth days. In side the egg capsules was observed nurse eggs, used by embryos as food resource. Communal spawning was observed in the laboratory.

\section{DISCUSSION}

The egg capsules of Pisania pusio are different from the other buccinids as Buccinum undatum Linnaeus, 1758 which secretes a proteinaceous capsules, each contain a clutch of eggs (Hughes, 1986).

According to Hughes (1986) the buccinid Buccinum undatum has a communal spawing, the same was observed to Pisania pusio.

Pisania maculosa (Lamarck, 1822) has nurse eggs (Fretter, 1984) and Pisania pusio also has nurse eggs.

In prosobranchs that swallow a large amount of nutritive eggs, the first formed shell is not calcified, it is elastic and is extended in the course of the tora e of ingested eggs, late cal ification occurs (Moor, 1983), same observation also was found in Pisania pusio.

Winner (1991) studying the egg masses of Pisania tincta found the average of the egg capsules were $4.5 \mathrm{~mm}$ in diameter bigger than it was found for Pisania pusio.

Pisania pusio laid the egg masses on the smooth surface on dead shells and on the glass of aquaria,

Tropical Oceanography, Recife, v. 33, n. 2, p. 159-162, 2005. 
the same type of smooth surface for spawning was found for the species Pisania tincta (Winner, 1991).

According to Fretter (1984) the species of the genus Buccinum does not have free larval stage, although in Pisania pusio a free late larval stage was found.

Pisania pusio has sexual dimorphism in the radula when the male radula is longer than the females (Matthews-Cascon et al., 2005). Besides the differences in the size, Pisania pusio present sexual dimorphism in the shape of the radular teeth (Matthews-Cascon et al., 2005).

\section{ACKNOWLEDGEMENTS}

We are very grateful to Dr. Paulo Cascon who provided useful insights and for revising English language and the Ph.D student Luis Ernesto Arruda Bezerra for the manuscript review.

\section{LITERATURE CITED}

FRETTER, V. Prosobranchs In: TOMPA, A.S.; VERDONK, N.H.; van.den BIGGELAAR, J.A.M. The Mollusca vol. 7 Reproduction., New York: Academic Press Inc., 1984. p. 1 - 45.

HUGHES, R.N. A functional biology of marine gastropods. Baltimore: The Johns Hopkins University Press, 1986. 245 p.

MATTHEWS-CASCON, H.; ALENCAR, H.A.P.; RABAY, S.G.; MOTA, R.M.S. Sexual dimorphism in the radula of Pisania pusio (Linnaeus, 1758) (Mollusca, Gastropoda, Buccinidae). Thalassas, Vigo, v. 21, n. 1, p. 29-33, 2005.

MOOR, B. Organogenesis In: TOMPA, A.S.; VERDONK, N.H.; van.den BIGGELAAR, J.A.M. The Mollusca vol. 3 Development, New York: Academic Press Inc., 1983. p.123 - 177.

RIOS, E.C. Seashells of Brazil. Rio Grande, RS: Editora da Furg, 1994. 345 p. WINNER, B.E. A field guide to molluscan spawn Vol. II. Florida, 1991. 94 p. 


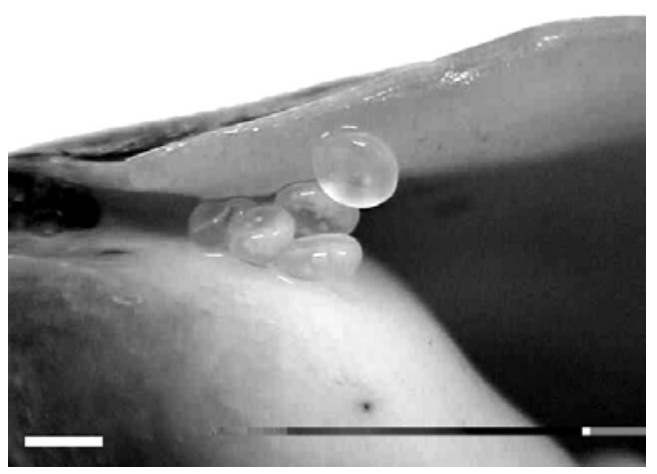

Figure 2 - Spawn of Pisania pusio on shell of Turbinella laevigata (Mollusca: Gastropoda). The white bar measure $5 \mathrm{~mm}$. 